\title{
Glucocorticoids dexamethasone and prednisolone suppress fibroblast growth factor 23 (FGF23)
}

\author{
Martina Feger ${ }^{1} \cdot$ Franz Ewendt $^{2} \cdot$ Jörg Strotmann ${ }^{1} \cdot$ Holger Schäffler $^{3} \cdot$ Daniela Kempe-Teufel $^{4} \cdot$ Philipp Glosse $^{2}$. \\ Gabriele I. Stangl ${ }^{2} \cdot$ Michael Föller $^{1}$
}

Received: 28 July 2020 / Revised: 29 December 2020 / Accepted: 5 January 2021 / Published online: 30 January 2021

(C) The Author(s) 2021

\begin{abstract}
Fibroblast growth factor 23 (FGF23) is a hormone mainly secreted by bone cells. Its most prominent effects are the regulation of renal phosphate reabsorption and calcitriol (active vitamin $\mathrm{D}, 1,25(\mathrm{OH})_{2} \mathrm{D}_{3}$ ) formation, effects dependent on its co-receptor $\alpha$ Klotho. Besides these actions, further paracrine and endocrine effects exist. The production of FGF23 is regulated by $1,25(\mathrm{OH})_{2} \mathrm{D}_{3}$, parathyroid hormone, dietary phosphate intake, iron status, as well as inflammation. Glucocorticoids are hormones with anti-inflammatory properties and are, therefore, widely used for acute and chronic inflammatory diseases, autoimmune disorders, and malignancies. The present study explored whether glucocorticoids influence the production of FGF23 in vitro as well as in mice. Fgf23 transcription was analyzed by semi-quantitative real-time PCR. Serum concentrations of FGF23 and $1,25(\mathrm{OH})_{2} \mathrm{D}_{3}$ were measured by ELISA. Urinary phosphate and $\mathrm{Ca}^{2+}$ excretion were determined in metabolic cages. As a result, in UMR106 rat osteoblast-like cells and in MC3T3-E1 cells, both, dexamethasone and prednisolone, downregulated Fgf 23 transcription and FGF23 protein synthesis. Dexamethasone increased Dmp1 and Phex (encoding FGF23-regulating genes) as well as Nfkbia (encoding NFKB inhibitor IKB $\alpha$ ) transcription in UMR106 cells. In mice, a single injection of dexamethasone or prednisolone was followed by a significant decrease of serum C-terminal and intact FGF23 concentration and bone Fgf23 mRNA expression within $12 \mathrm{~h}$. These effects were paralleled by increased renal phosphate excretion and enhanced $1,25(\mathrm{OH})_{2} \mathrm{D}_{3}$ formation. We conclude that a single glucocorticoid treatment strongly downregulates the FGF23 plasma concentration.
\end{abstract}

\section{Key messages}

- Glucocorticoids dexamethasone and prednisolone suppress the formation of bone-derived hormone fibroblast growth factor 23 (FGF23) in vitro.

- The effect is accompanied by an upregulation of Dmp1, Phex, and IKB $\alpha$, negative regulators of FGF23, in UMR106 osteoblast-like cells.

- Glucocorticoid receptor antagonist RU-486 attenuates the effect of dexamethasone on FGF23, Dmp1, and Phex.

- In mice, a single glucocorticoid dose suppresses FGF23 and enhances $1,25(\mathrm{OH})_{2} \mathrm{D}_{3}$ (active vitamin $\mathrm{D}$ ).

Keywords Phosphate $\cdot 1,25(\mathrm{OH})_{2} \mathrm{D}_{3} \cdot \alpha$ Klotho $\cdot$ Inflammation

Michael Föller

michael.foeller@uni-hohenheim.de

1 Department of Physiology, University of Hohenheim, Garbenstraße 30, 70599 Stuttgart, Germany

2 Institute of Agricultural and Nutritional Sciences, Martin Luther University Halle-Wittenberg, 06120 Halle (Saale), Germany

3 Department of Gastroenterology, University of Rostock, 18057 Rostock, Germany

4 Department of Endocrinology, University of Tübingen, 72076 Tübingen, Germany

\section{Introduction}

The phosphaturic hormone fibroblast growth factor 23 (FGF23) is mainly synthesized in bone cells (osteoblasts/osteocytes) and affects renal phosphate handling and the production of calcitriol $\left(1,25(\mathrm{OH})_{2} \mathrm{D}_{3}\right)$, the active form of vitamin $\mathrm{D}$ $[1,2]$. These effects are mediated by the concerted action of the receptor for FGF23 (FGFR) and transmembrane protein $\alpha$ Klotho which serves as a co-receptor [2]. Binding of FGF23 to this receptor results in the internalization of secondaryactive phosphate transporter $\mathrm{NaP}_{\mathrm{i}} \mathrm{II}$ a residing in the apical cell 
membrane of the proximal tubule and in downregulation of CYP27B1, the key enzyme for the generation of $1,25(\mathrm{OH})_{2} \mathrm{D}_{3}$ [1]. Hence, FGF23 lowers the plasma concentration of both, phosphate and $1,25(\mathrm{OH})_{2} \mathrm{D}_{3}$, thereby depending on $\alpha$ Klotho [1], an anti-aging protein [3]. Another target organ of FGF23 is the parathyroid gland where FGF23 regulates the production of parathyroid hormone, PTH, in a $\alpha$ Klotho-dependent manner $[4,5]$. Apart from this, FGF23 also exerts paracrine and further endocrine effects without the contribution of $\alpha$ Klotho: It induces hypertrophy of the left ventricle [6], regulates neutrophil recruitment [7], or stimulates the secretion of pro-inflammatory cytokines from the liver [8]. The induction of left ventricular hypertrophy may, at least in part, be due to indirect effects of FGF23, too, e.g., elevation of blood pressure [9-11]. Similarly, the FGF23 effect on inflammation in hepatocytes may also involve indirect actions, e.g., the induction of interleukin-6 production in Kupffer cells that affect hepatocytes [12].

The dramatic phenotype of FGF23- or $\alpha$ Klotho-deficient mice is mostly characterized by sequelae of massive hyperphosphatemia which are far-reaching and affect most organs and tissues: The animals suffer from rapid aging with a markedly shortened life span and exhibit a wide range of aging associated diseases [13, 14]. A low phosphate or low vitamin D diet prevents such consequences [15]. Similar to FGF23- or $\alpha$ Klotho-deficient mice, patients with chronic kidney disease (CKD), which are typically characterized by high FGF23 levels and low $\alpha$ Klotho expression, suffer from the sequelae of hyperphosphatemia which drastically increase their cardiovascular mortality [16]. The FGF23 plasma concentration rises early in CKD and correlates well with disease activity, progression and outcome making FGF23 a valuable disease biomarker in CKD [17, 18]. In addition, high FGF23 plasma levels are found in cardiovascular, metabolic, and inflammatory disorders, suggesting that FGF23 may be a general disease biomarker [19].

The regulation of FGF 23 production is only partly understood: Important regulators include $1,25(\mathrm{OH})_{2} \mathrm{D}_{3}[20]$ and PTH [21]. Both strongly affect the plasma phosphate concentration as does FGF23. Therefore, and since FGF23 also regulates $1,25(\mathrm{OH})_{2} \mathrm{D}_{3}$ and $\mathrm{PTH}$, all three hormones are part of a complex feedback loop regulating plasma phosphate. Further regulators are alimentary phosphorus intake [22], inflammation [23], and inflammatory cytokines including tumor necrosis factor- $\alpha$ [24], interleukin-6 [25], the iron status [26], or erythropoietin [27]. Mechanistically, the transcription of the FGF23 gene is dependent on transcription factor Nurr1 [21], NFKB upregulating $\mathrm{Ca}^{2+}$ release-activated $\mathrm{Ca}^{2+}$ channel (CRAC) Orail $[28,29]$, as well as insulin-dependent phosphoinositide 3-kinase (PI3K)/protein kinase B (PKB)/Akt/forkhead box O1 (FOXO1) signaling [30]. Orail-mediated store-operated $\mathrm{Ca}^{2+}$ entry (SOCE) is a fundamental driver of $F G F 23$ gene expression $[28,31]$. The aforementioned signaling has, thus far, only been verified for FGF23 production in bone, not for other tissues.

Cortisol is the main glucocorticoid in humans produced by the adrenal gland [32]. Glucocorticoids are stress hormones with a long list of metabolic (particularly affecting glucose and lipid metabolism) and immunological effects [32]. Synthetic glucocorticoids such as prednisolone or dexamethasone are widely used in the therapy of inflammatory diseases owing to their strong and multiple anti-inflammatory properties [33]: Glucocorticoids inhibit the production of proinflammatory prostaglandins through annexins [34], induce apoptosis of T cells [35], or suppress the transcriptional activity of pro-inflammatory transcription factor complex NFKB [36]. As steroid hormones, glucocorticoids bind to an intracellular receptor, the glucocorticoid receptor (GR), which translocates to the nucleus, binds DNA, and induces or represses the transcription of target genes [37].

Glucocorticoid therapies are initiated for a plethora of frequent inflammatory and autoimmune diseases including glomerulonephritis, rheumatoid arthritis, asthma, or inflammatory bowel disease to name a few. They are limited due to a variety of adverse effects. These effects are dependent on the dose and duration of therapy, but are often observed and include steroid diabetes, hypertension, thin skin, muscle atrophy, obesity, and loss of bone mass due to direct and indirect effects [38]: Glucocorticoids affect osteoblast and osteoclast activity [39] but also impact on phosphate metabolism by regulating renal phosphate transporter $\mathrm{NaP}_{\mathrm{i}} \mathrm{IIa}$ [40].

Recently, a study suggested an inhibitory effect of glucocorticoids on FGF23 [41], whereas another study suggested a stimulatory effect [42]. Both studies focused on long-term effects of glucocorticoids which may include secondary cellular responses owing to the broad spectrum of glucocorticoid effects. We therefore sought to study the cellular effects of an acute glucocorticoid treatment, both in vitro and in vivo. To this end, we analyzed the production of FGF23 in UMR106 osteoblast-like cells and in MC3T3-E1 cells as well as in mice treated with glucocorticoids.

\section{Materials and methods}

\section{Cell culture}

Experiments were performed in UMR106 rat osteoblastic osteosarcoma cells (CRL-1661; ATCC, Manassas, VA, USA). UMR106 cells were cultured in Dulbecco's Modified Eagle Medium (DMEM) high glucose (Gibco, Life Technologies, Darmstadt, Germany) supplemented with $10 \%$ fetal bovine serum (FBS) (Gibco, Life Technologies), $100 \mathrm{U} / \mathrm{ml}$ penicillin, and $100 \mu \mathrm{g} / \mathrm{ml}$ streptomycin (Gibco, Life Technologies). Twenty-four hours after seeding, the cells were treated with the indicated concentrations of dexamethasone, prednisolone 
(both from Sigma-Aldrich, Schnelldorf, Germany; stock dissolved in dimethyl sulfoxide (DMSO)), or glucocorticoid receptor antagonist RU-486 (Tocris Bioscience, Bristol, UK; stock dissolved in ethanol) for 24 or $48 \mathrm{~h}$, as indicated. Control cells were incubated with the appropriate volume of DMSO or ethanol (both from Sigma-Aldrich), respectively. Untreated UMR106 cells do not express appreciable amounts of $F g f 23$ mRNA as reflected by the cycle threshold $(\mathrm{Ct})$ of Fgf 23 in semi-quantitative RT-PCR analysis. Calcitriol potently upregulates $F g f 23$ expression in UMR106 cells. In line with this, the arithmetic means $\pm \operatorname{SEM}(n=3)$ of the $\mathrm{Ct}$ values of UMR 106 cells were $34.0 \pm 0.75$ (untreated) and $28.0 \pm 0.06$ (treated with $10 \mathrm{nM}$ calcitriol for $24 \mathrm{~h}$ ). Therefore, all cell culture treatments were carried out in the presence of $10 \mathrm{nM}$ calcitriol (Tocris Bioscience) [43].

MC3T3-E1 Subclone 4 mouse pre-osteoblast cells (CRL2593; ATCC) were cultured in alpha-Minimum Essential Medium ( $\alpha$-MEM) containing nucleosides and $2 \mathrm{mM} \mathrm{L-}$ glutamine (Gibco, Life Technologies) and supplemented with $10 \% \mathrm{FBS}, 100 \mathrm{U} / \mathrm{ml}$ penicillin, and $100 \mu \mathrm{g} / \mathrm{ml}$ streptomycin. The cells were used from passages 20 to 23 . The cells were seeded on rat tail type I collagen-coated 12 -well plates $(80,000$ cells per well) for $24 \mathrm{~h}$. Differentiation was induced by culturing the cells in osteogenic medium containing $50 \mu \mathrm{g} / \mathrm{ml}$ ascorbic acid (Sigma-Aldrich), and $4 \mathrm{mM} \beta$-glycerophosphate (AppliChem, Darmstadt, Germany). Cells were differentiated for 6 or 13 days and then treated for $24 \mathrm{~h}$ with dexamethasone $(30 \mathrm{nM}$ or $100 \mathrm{nM})$ or vehicle in the presence of calcitriol $(10 \mathrm{nM})$ throughout the experiment or $24 \mathrm{~h}$ before harvesting the cells, as indicated.

\section{Analysis of FGF23 protein in the cell culture medium}

The cell culture supernatants of UMR106 cells treated with $30 \mathrm{nM}$ or $100 \mathrm{nM}$ dexamethasone or vehicle in the presence of $10 \mathrm{nM}$ calcitriol for $48 \mathrm{~h}$ were collected and stored at $-70{ }^{\circ} \mathrm{C}$. The medium was concentrated utilizing Vivaspin 6 concentrators (Sartoritus, Göttingen, Germany). C-terminal FGF23 and intact FGF23 were determined by commercial ELISA Kits (Mouse/Rat FGF-23 (C-Term), Mouse/Rat FGF-23 (Intact); both from Immutopics, San Clemente, CA, USA) according to the manufacturer's instructions.

\section{Animal experiments and tissue collection}

All animal experiments were conducted in accordance with the federal law for the welfare of animals and were approved by the respective state government. The mice had free access to tap water and standard rodent chow mainly based on wheat, soybeans, barley, oat hulls, and sugar beet pulp with a rough composition owing to the nature of the plant products (V1534: app. $0.7 \%$ phosphorus, $1.0 \%$ calcium; Ssniff, Soest, Germany; more details can be found at https://www.ssniff.de/) ad libitum.

Adult wild-type mice (C57BL/6; Charles River, Sulzfeld, Germany) of both sexes were injected intraperitoneally with a single dose of dexamethasone $(20 \mathrm{mg} / \mathrm{kg}$ body weight; Fortecortin ${ }^{\circledR}$, Merck, Darmstadt, Germany; formulation: $4.37 \mathrm{mg} / \mathrm{ml}$ dexamethasone dihydrogen phosphate disodium, sodium edetate, creatinine, sodium citrate, $1 \mathrm{~mol} / \mathrm{l}$ sodium hydroxide and water for injections) or prednisolone $(20 \mathrm{mg} / \mathrm{kg}$ body weight; PredniGalen $®$, GALENpharma, Kiel, Germany; formulation: $10 \mathrm{mg} / \mathrm{ml}$ prednisolone acetate, macrogol 4000, polysorbate 80 , disodium phosphate dodecahydrate, sodium dihydrogen phosphate dihydrate, water for injections and $15 \mathrm{mg} / \mathrm{ml}$ benzyl alcohol). As control, $0.9 \%$ saline was chosen since an exact formulation of the drugs was not available. After $12 \mathrm{~h}$, blood was taken by retro-orbital puncture under isoflurane anesthesia. The animals were sacrificed and kidneys were immediately isolated and snap-frozen in liquid nitrogen. Bones were also removed and prepared by thoroughly scrubbing the femur and tibia to remove other tissues. Next, both epiphyses were cut, and the bone marrow was flushed out with $0.9 \%$ saline.

\section{Serum biochemistry}

Photometric methods were used for the analysis of the serum phosphate (Analyticon Biotechnologies, Lichtenfels, Germany) and $\mathrm{Ca}^{2+}$ (Fuji DRI-CHEM NX500i, Fujifilm, Düsseldorf, Germany) concentration. For the serum concentration of $1,25(\mathrm{OH})_{2} \mathrm{D}_{3}$ (IDS, Boldon, UK), C-terminal FGF23, intact FGF23, and intact PTH (all three from Immutopics) ELISA kits were employed.

\section{Renal parameters}

To assess renal phosphate and $\mathrm{Ca}^{2+}$ excretion, the mice were placed individually in siliconized metabolic cages (Tecniplast, Hohenpeissenberg, Germany). Standard chow pellets tend to crumble when eaten by mice. Hence, they cannot be used in metabolic cages since they would contaminate the collected urine. This is why we used a control diet with pellets with different consistency and precisely defined ingredients (C1000: $0.8 \%$ phosphorus, 0.9\% calcium; Altromin, Lage, Germany; more detailed information can be found at https:// altromin.de/). Following a 3-day habituation period, mice were treated with $20 \mathrm{mg} / \mathrm{kg}$ body weight dexamethasone or vehicle. After $12 \mathrm{~h}$, a small amount of blood was withdrawn. Additionally, 24-h urine was collected under water-saturated oil starting from the time of injection. The urinary phosphate and $\mathrm{Ca}^{2+}$ concentrations were measured by means of commercial assays (both from Analyticon Biotechnologies, Lichtenfels, Germany). Prior to the determination of $\mathrm{Ca}^{2+}$, 24-h urine was acidified with hydrochloric acid in order to 
dissolve calcium salts. A creatinine detection kit (Jaffé method, Labor + Technik, Berlin, Germany) was employed for the measurement of the urinary creatinine concentration. Serum creatinine was determined by an enzymatic method (Chrystal Chem, Zaandam, Netherlands).

\section{Semi-quantitative real-time PCR}

Total RNA was extracted from UMR106 cells, MC3T3-E1 cells, or mouse kidneys using peqGold Trifast ${ }^{\mathrm{TM}}$ reagent

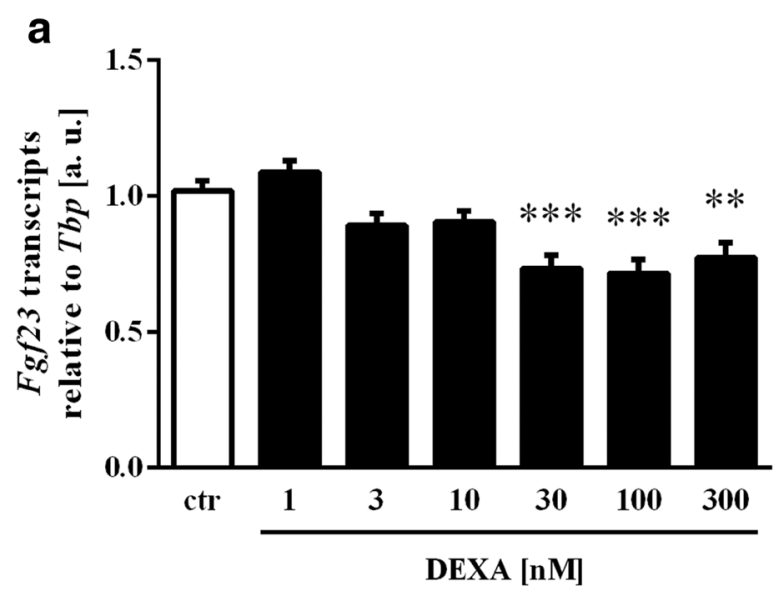

b

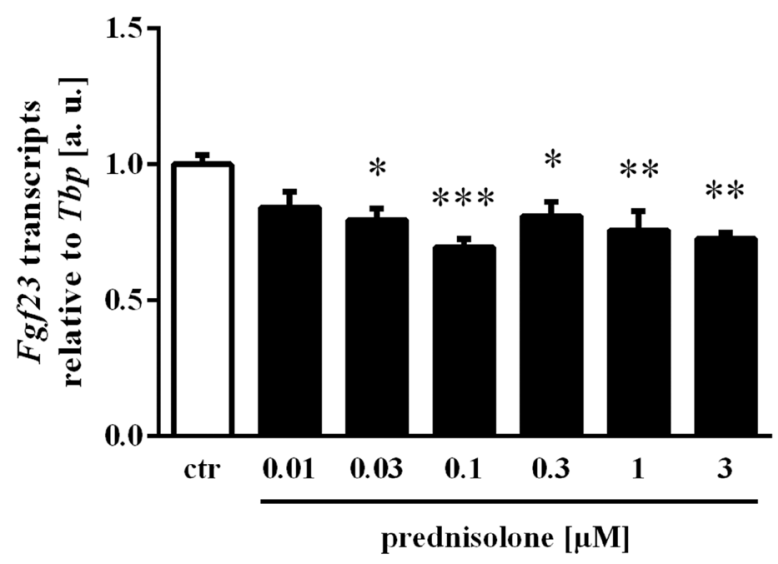

C

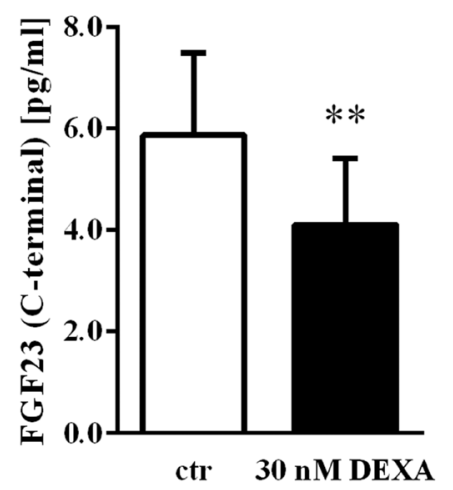

(Peqlab, Erlangen, Germany). Total RNA (1.2 $\mu \mathrm{g})$ was reverse-transcribed with the GoScript ${ }^{\mathrm{TM}}$ Reverse Transcription System (Promega, Mannheim, Germany) and random primers (Promega). One $\mu \mathrm{g}$ of total RNA was used for first-strand cDNA from MC3T3-E1 cells with persistent calcitriol stimulation.

Total bone RNA was initially extracted with peqGold Trifast $^{\mathrm{TM}}$ reagent followed by a DNase treatment and a purification step using the RNase-free DNase Set and the RNeasy Mini Kit (both from QIAGEN, Hilden, Germany). First-strand

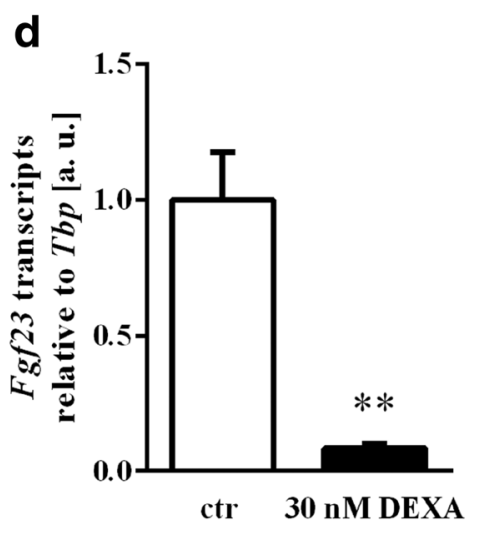

e

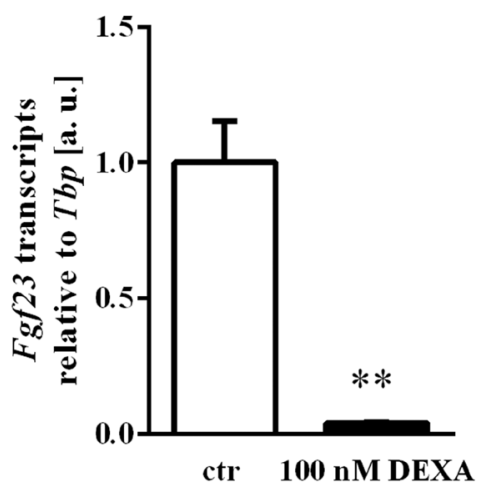

f

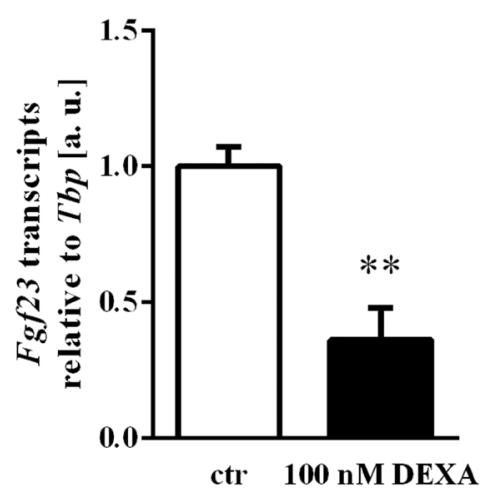


Fig. 1 Effect of glucocorticoids on $F g f 23$ expression and protein synthesis in UMR106 and MC3T3-E1 cells. Arithmetic means \pm SEM ( $n=6$, arbitrary units (a. u.)) of relative $F g f 23$ mRNA expression normalized to $T b p$ transcript levels in UMR106 cells incubated without (white bars) or with (black bars) dexamethasone (DEXA, a) or prednisolone (b) at the indicated concentrations in the presence of calcitriol $(10 \mathrm{nM})$ for 24 h. $* p<0.05, * * p<0.01, * * * p<0.001$ indicate significant differences compared to UMR106 cells treated with $10 \mathrm{nM}$ calcitriol only. (c) Arithmetic means \pm SEM of C-terminal FGF23 protein concentration in the cell culture supernatant of UMR106 cells treated with vehicle (white bars) or with $30 \mathrm{nM}(n=8)$ or $100 \mathrm{nM}(\mathrm{n}=6)$ dexamethasone (DEXA, black bars) in the presence of calcitriol $(10 \mathrm{nM})$ for $48 \mathrm{~h} . * p<0.05$, $* * p<0.01$, indicate significant difference compared to UMR106 cells treated with $10 \mathrm{nM}$ calcitriol only. Arithmetic means $\pm \operatorname{SEM}(n=5$, arbitrary units (a. u.)) of relative $F g f 23$ mRNA expression normalized to $T b p$ transcript levels in MC3T3-E1 cells at day 7 of osteoblast differentiation incubated with vehicle (white bars) or $30 \mathrm{nM}$ (d) or $100 \mathrm{nM}$ (e) dexamethasone (DEXA, black bars) in the presence of calcitriol $(10 \mathrm{nM})$ for $24 \mathrm{~h}$. $* * p<0.01$ indicates significant difference compared to control cells. (f) Arithmetic means $\pm \operatorname{SEM}(n=4$, arbitrary units (a. u.)) of relative Fgf 23 mRNA expression normalized to $T b p$ transcript levels in MC3T3-E1 cells at day 14 in osteogenic differentiation medium containing calcitriol $(10 \mathrm{nM})$ and incubated with $100 \mathrm{nM}$ dexamethasone (DEXA, black bar) or vehicle (white bar) for $24 \mathrm{~h} . * * p<0.01$ indicates significant difference compared to vehicle-treated MC3T3-E1 cells. (a and b: one-way ANOVA followed by Dunnett's multiple comparisons test; $\mathbf{c}-\mathbf{f}$ : paired $t$ test)

cDNA was synthesized from $300 \mathrm{ng}$ of total bone RNA using the GoScript ${ }^{\mathrm{TM}}$ Reverse Transcription System.

For the analysis of relative transcript levels, semiquantitative real-time PCR (qRT-PCR) using GoTaq ${ }^{\circledR}$ qPCR Master Mix (Promega) was carried out. The reaction mix for the amplification of $2 \mu \mathrm{l}$ cDNA templates $(1.5 \mu \mathrm{l}$ cDNA in the case of bone $F g f 23$ expression analysis) contained $10 \mu \mathrm{l} 2 \mathrm{x}$ GoTaq ${ }^{\circledR}$ qPCR Master Mix (Promega), primers, and sterile water up to $20 \mu$ l. The qRT-PCR program was $95{ }^{\circ} \mathrm{C}$ for $2 \mathrm{~min}, 40$ cycles of denaturation at $95^{\circ} \mathrm{C}$ for $10 \mathrm{~s}$, annealing at primer-specific temperature for $30 \mathrm{~s}$, and extension at $72{ }^{\circ} \mathrm{C}$ for $25-30 \mathrm{~s}$.

The following primers $\left(5^{\prime} \rightarrow 3^{\prime}\right.$ orientation $)$ and annealing temperatures were used:

rat Dmpl $\left(62{ }^{\circ} \mathrm{C}\right)$ :

CGCCCATGGCAAATAGTGAC;

CGTGCTGTCTTCACTGGACT;

rat Fgf $23\left(57{ }^{\circ} \mathrm{C}\right)$ :

TAGAGCCTATTCAGACACTTC;

CATCAGGGCACTGTAGATAG;

rat Nfkbia $\left(58^{\circ} \mathrm{C}\right)$ :

AGACTCGTTCCTGCACTTGG;

TCTCGGAGCTCAGGATCACA;

rat Phex $\left(58^{\circ} \mathrm{C}\right)$ :

ATGGCTGGATAAGCAATAAC; GCTTTTTCAATCGCTTTCTC;

rat $\operatorname{Tbp}\left(57^{\circ} \mathrm{C}\right)$ :

ACTCCTGCCACACCAGCC;

GGTCAAGTTTACAGCCAAGATTCA; mouse Cyp24al $\left(58^{\circ} \mathrm{C}\right)$ :

CCCAAAGGAACAGTCTTAAC;

GGTCTAAACTTGTCAGCATC;

mouse Cyp27b1 $\left(58^{\circ} \mathrm{C}\right)$ :

AGTGTTGAGATTGTACCCTG; CGTATCTTGGGGAATTACATAG;

mouse Dmpl $\left(58^{\circ} \mathrm{C}\right)$ :

GAACAGTGAGTCATCAGAAG;

AAAGGTATCATCTCCACTGTC;

mouse $\mathrm{Fg} f 23\left(58^{\circ} \mathrm{C}\right)$ :

TCGAAGGTTCCTTTGTATGGA;

AGTGATGCTTCTGCGACAAGT;

mouse Gapdh $\left(58^{\circ} \mathrm{C}\right)$ :

GGTGAAGGTCGGTGTGAACG;

CTCGCTCCTGGAAGATGGTG;

mouse $\mathrm{K} 1\left(56^{\circ} \mathrm{C}\right)$ :

CCTTAAAAGCAATCAGACTGG;

GAAAGCCATTGTCCTCTATC;

mouse Nfkbia $\left(57^{\circ} \mathrm{C}\right)$ :

GGAGACTCGTTCCTGCACTTGG;

CTCAGCAATTCCTGGCTGGT;

mouse Phex $\left(57^{\circ} \mathrm{C}\right)$ :

TCATTGATACCAGACTCTACC;

CAATGGTTTTCTTCCTCTCG;

mouse Slc $34 a 1\left(58{ }^{\circ} \mathrm{C}\right)$ :

AATGCAACCATATCTTCGTG;

GGAAAGTCTGTGTTGATGAC;

mouse Tbp $\left(60^{\circ} \mathrm{C}\right)$ :

CCAGACCCCACAACTCTTCC;

CAGTTGTCCGTGGCTCTCTT.

Calculated mRNA expression levels were normalized to the expression levels of Tbp (rat UMR106 cells and mouse MC3T3-E1 cells) and Gapdh (mouse tissue). Relative quantification of gene expression was performed using the $2^{-\Delta \Delta \mathrm{Ct}}$ method.

\section{Statistics}

Data are shown as arithmetic means \pm SEM, and $n$ represents the number of mice per group or the number of independent cell culture experiments, respectively. Normality was tested with Shapiro-Wilk test. Two groups were compared by paired $t$ test or unpaired two-tailed $t$ test (Welch's correction was applied for data with different standard deviations) or MannWhitney U test (for data not passing normality test). Statistical testing of more than two groups was performed by one-way ANOVA followed by Dunnett's or Tukey's multiple comparisons test (homoscedastic data) or Games-Howell test (heteroscedastic data) as indicated in the figure legends. Only differences with $P<0.05$ were considered statistically significant. 
a
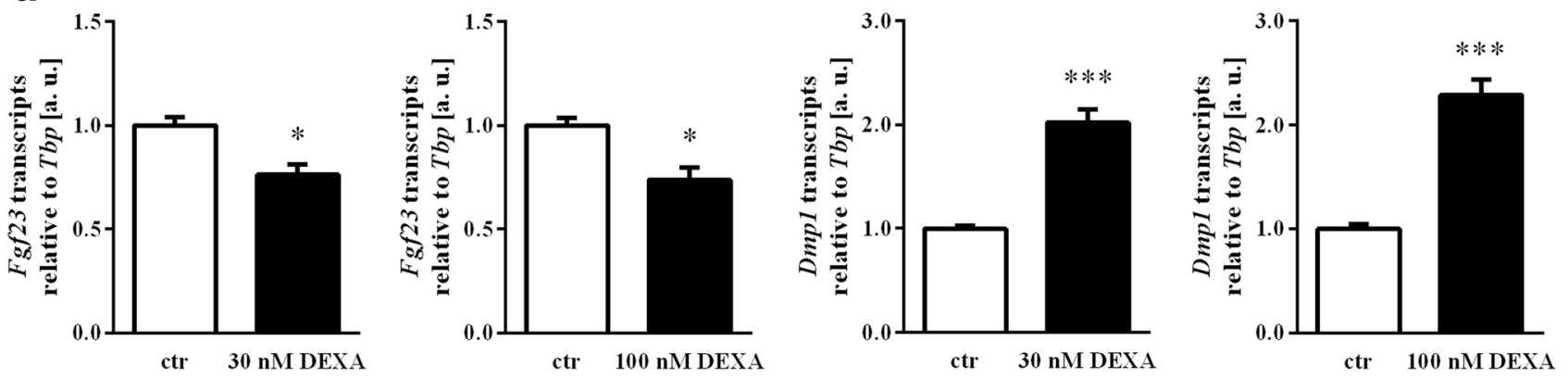

b
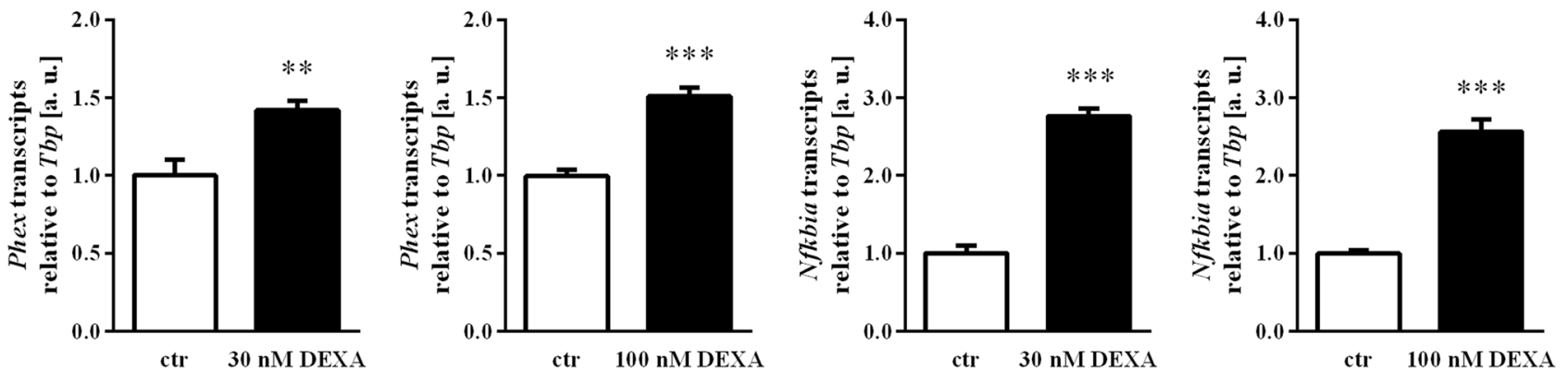

C

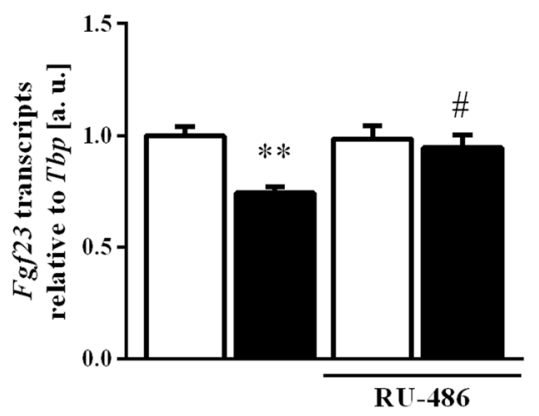

Fig. 2 Impact of dexamethasone and glucocorticoid antagonist RU-486 on regulators of $F g f 23$ expression. Arithmetic means \pm SEM (arbitrary units (a. u.)) of relative mRNA transcript levels of Fgf23, Dmpl (a), Phex, and Nfkbia (b), all normalized to Tbp, in UMR106 cells treated with $30 \mathrm{nM}(n=9)$ or $100 \mathrm{nM}$ dexamethasone $(n=7)$ (DEXA, black bars) or vehicle only (white bars) in the presence of $10 \mathrm{nM}$ calcitriol for $24 \mathrm{~h}$. $* p<0.05, * * p<0.01, * * * p<0.001$ indicate statistically significant difference from vehicle-treated cells. Arithmetic means \pm SEM $(n=6$, arbitrary units (a. u.)) of relative mRNA transcript levels of Fgf23 (c), Dmp1

\section{Results}

We used UMR106 osteoblast-like cells to study whether dexamethasone, a synthetic glucocorticoid with high potency that is widely used in clinical practice, influences FGF23 production. The cells were incubated with 1-300 nM dexamethasone for $24 \mathrm{~h}$, and $F g f 23$ transcripts were determined by qRT-PCR. The dose dependence of the dexamethasone effect on Fgf23 gene expression is depicted in Fig. 1a. Similarly, the

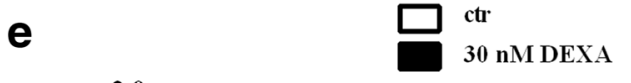
$24 \mathrm{~h}$ ) UMR106 cells treated without (white bars) or with $30 \mathrm{nM}$ dexamethasone (DEXA, black bars) in the absence or presence of the glucocorticoid receptor antagonist RU-486 (30 nM) for $24 \mathrm{~h}$. $* p<0.05$, $* * p<0.01, * * * p<0.001$ indicate statistically significant difference from vehicle-treated cells (first bar). $\# p<0.05, \# \# p<0.01$ indicate statistically significant difference from the absence of RU-486 ( $2^{\text {nd }}$ bar vs. $4^{\text {th }}$ bar). (a and b: paired $t$ test; c-e: one-way ANOVA followed by Tukey's multiple comparisons test (c and e) or Games-Howell test (d))

expression of $F g f 23$ mRNA was reduced by the synthetic glucocorticoid prednisolone that is also widely used in the treatment of autoimmune diseases (Fig. 1b). In order to test whether dexamethasone also affects FGF23 secretion, we analyzed the FGF23 protein concentration into the cell culture supernatant. As a result, the concentration of C-terminal FGF23 in the cell culture medium of cells incubated with $30 \mathrm{nM}$ (Fig. 1c, left panel) or $100 \mathrm{nM}$ (Fig. 1c, right panel) dexamethasone for $48 \mathrm{~h}$ was significantly lower than in the 
medium of vehicle-treated cells. We also tried to determine intact FGF23, however, for $n=7$ out of $n=14$ experiments, the concentration of intact FGF23 was below the detection limit. For the remaining $n=7$ measurements, the concentration of intact FGF23 was $3.49 \pm 0.51 \mathrm{pg} / \mathrm{ml}$ in the supernatant of UMR106 cells incubated for $48 \mathrm{~h}$ without and $2.52 \pm$ $0.21 \mathrm{pg} / \mathrm{ml}$ in the supernatant of cells incubated with $30 \mathrm{nM}$ dexamethasone $(p=0.12)$.

MC3T3-E1 cells were used in further experiments to verify the glucocorticoid effect on FGF23. Also in these cells dexamethasone potently lowered Fgf23 gene expression (Figs. 1df). The effect could be observed in cells differentiated for 6 days (Figs. 1d, e) or 13 days (Fig. 1f) and then treated with $30 \mathrm{nM}$ (Fig. 1d) or $100 \mathrm{nM}$ (Figs. 1e, f) dexamethasone for $24 \mathrm{~h}$.

A new series of experiments addressed the impact of dexamethasone on regulators of $F g f 23$ expression. Again, $30 \mathrm{nM}$ or $100 \mathrm{nM}$ dexamethasone suppressed $F g f 23$ gene expression in UMR106 cells (Fig. 2a). Importantly, Dmp1 (Fig. 2a, right panels) and Phex (Fig. 2b, left panels) mRNA transcript levels were significantly higher in dexamethasone-treated $(30 \mathrm{nM}$ or $100 \mathrm{nM}$ ) UMR106 cells than in control cells. Glucocorticoids have strong anti-inflammatory properties owing to their inhibitory effect on NFKB. Hence, we studied the expression of IкB $\alpha$ (encoded by Nfkbia), a cytoplasmic protein that inhibits nuclear translocation of NFKB. As shown in Fig. 2b, right panels, Nfkbia expression was significantly enhanced following treatment with 30 or $100 \mathrm{nM}$ dexamethasone for $24 \mathrm{~h}$.

We also investigated the contribution of the glucocorticoid receptor to the dexamethasone effect on FGF23 by performing experiments with glucocorticoid receptor antagonist RU-486. As a result, $30 \mathrm{nM}$ RU-486 significantly attenuated the dexamethasone (30 nM) effect on Fgf23 transcripts (Fig. 2c), Dmpl transcripts (Fig. 2d) and Phex transcripts (Fig. 2e). Thus, the dexamethasone effect is - at least in partmediated by the glucocorticoid receptor.

Since the cells had to be treated with $1,25(\mathrm{OH})_{2} \mathrm{D}_{3}$ to upregulate $\mathrm{Fgf} 23$ gene expression, the dexamethasone effect could, at least in theory, have been due to an interaction of dexamethasone with $1,25(\mathrm{OH})_{2} \mathrm{D}_{3}$ signaling. Therefore, we tested whether the dexamethasone effect on upstream regulators of $F g f 23$ gene expression was different between cells treated with $1,25(\mathrm{OH})_{2} \mathrm{D}_{3}$ or left untreated. As demonstrated in suppl. Fig. 1, the effect of $30 \mathrm{nM}$ dexamethasone on Dmp 1 expression (suppl. Fig. 1a), Phex expression (suppl. Fig. 1b), or Nfkbia expression (suppl. Fig. 1c) was comparable between cells treated with $1,25(\mathrm{OH})_{2} \mathrm{D}_{3}$ or left untreated.

Our in vitro results suggest an inhibitory effect of glucocorticoids on FGF23 synthesis. We therefore sought to investigate whether the regulation of FGF23 by glucocorticoids has in vivo relevance given their frequent use for medical purposes. Mice were sham-treated or treated with a single dose of dexamethasone. Twelve hours later, blood was collected, and the serum concentration of C-terminal and intact FGF23 was determined. As demonstrated in Fig. 3, dexamethasone is given only once significantly and markedly reduced the serum level of both, C-terminal (Fig. 3a) and intact (Fig. 3b) FGF23. To check whether the lower FGF23 serum concentration is paralleled by reduced gene expression, we determined $\mathrm{Fg} f 23$ transcript levels in the bone of dexamethasone-treated animals, the main site of FGF23 production. As a result, dexamethasone downregulated $F g f 23$ gene expression in the bone, pointing to a highly relevant inhibitory effect of glucocorticoids on the production of this hormone even after a single dose (Fig. 3c, first panel). The effect was paralleled by upregulation of Nfkbia expression (Fig. 3c, last panel), whereas Dmpl and Phex expressions were not significantly modified (Figs. 3c, $2^{\text {nd }}$ and $3^{\text {rd }}$ panel). Moreover, a single injection of prednisolone similarly lowered the C-terminal (Fig. 3d) and intact FGF23 serum level (Fig. 3e).

One of the main actions of FGF23 is the suppression of the formation of $1,25(\mathrm{OH})_{2} \mathrm{D}_{3}$ by downregulation of $C Y P 27 B 1$, the key renal enzyme for the hydroxylation of $25(\mathrm{OH}) \mathrm{D}_{3}$. Dexamethasone-dependent inhibition of FGF23 formation is therefore likely to also affect the serum concentration of $1,25(\mathrm{OH})_{2} \mathrm{D}_{3}$. As expected, the single dose of dexamethasone resulted in a surge of the serum concentration of $1,25(\mathrm{OH})_{2} \mathrm{D}_{3}$ (Fig. 4a). PTH was not affected by dexamethasone treatment (Fig. 4b). Enhanced 1,25(OH $)_{2} \mathrm{D}_{3}$ formation upon short-term glucocorticoid administration was paralleled by increased renal expression of Cyp27b1 (Fig. 4c). The expression of Cyp24a1, the renal enzyme catalyzing the inactivation of $1,25(\mathrm{OH})_{2} \mathrm{D}_{3}$ was, however, not significantly affected by dexamethasone (Fig. 4d).

FGF23 directly induces renal phosphate excretion by targeting $\mathrm{NaP}_{\mathrm{i}} \mathrm{II}$ (encoded by Slc34al), the main renal $\mathrm{Na}^{+}-$ dependent phosphate transporter. To study the impact of a single dose of dexamethasone on renal phosphate handling, metabolic cage studies were conducted. Dexamethasone significantly increased creatinine clearance (Fig. 5a), a finding in line with the literature [44]. As demonstrated in Fig. 5b and d, dexamethasone treatment resulted in an increase in renal phosphate excretion, which was paralleled by a lower serum phosphate level, within $12 \mathrm{~h}$. This finding is also in line with an earlier report demonstrating a direct effect of dexamethasone on $\mathrm{NaP}_{\mathrm{i}} \mathrm{II}$ [40]. The serum $\mathrm{Ca}^{2+}$ concentration (Fig. 5c) was not affected by the glucocorticoid within $12 \mathrm{~h}$, whereas dexamethasone treatment tended to increase urinary $\mathrm{Ca}^{2+}$ excretion; however, this effect did not reach statistical significance (Fig. 5e). In line with phosphaturia upon dexamethasone treatment, the renal expression of Slc34al was reduced in animals receiving the glucocorticoid (Fig. 5f), as revealed by qRTPCR. FGF23-mediated regulation of urinary phosphate excretion is dependent on its co-receptor $\alpha$ Klotho. As shown in Fig. $5 \mathrm{~g}$, treatment with dexamethasone did not significantly affect $\mathrm{Kl}$ mRNA expression in the kidney. 
a

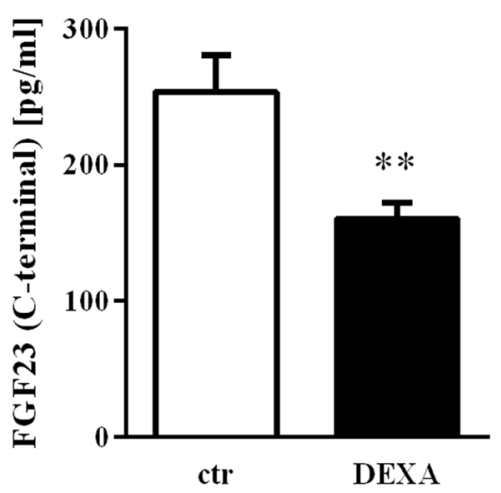

C
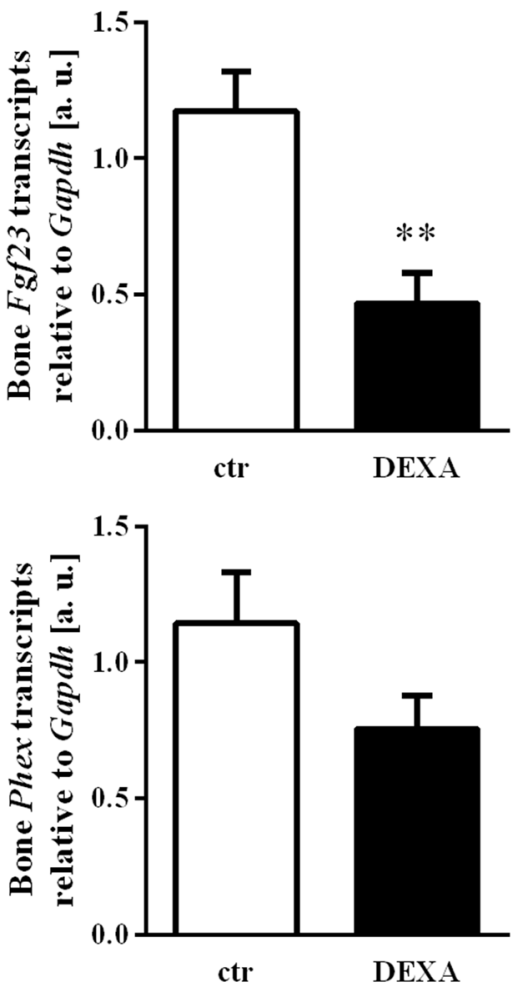

d

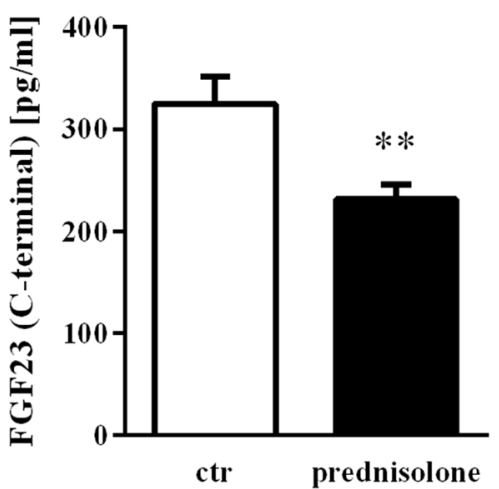

b
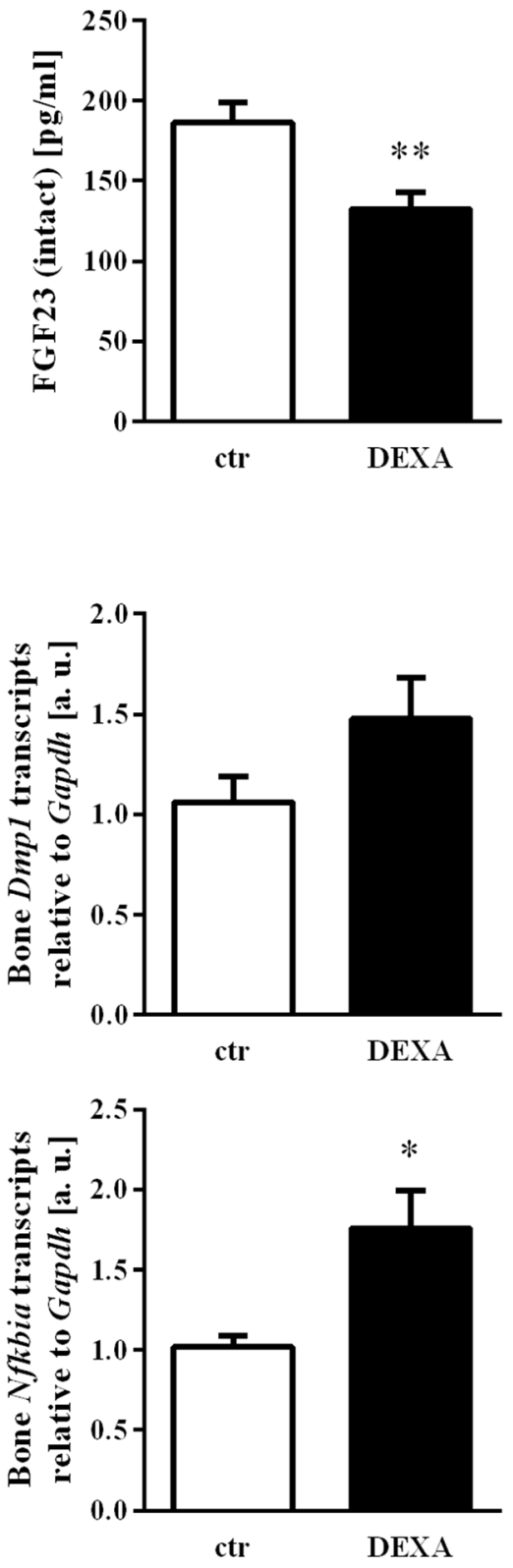

e

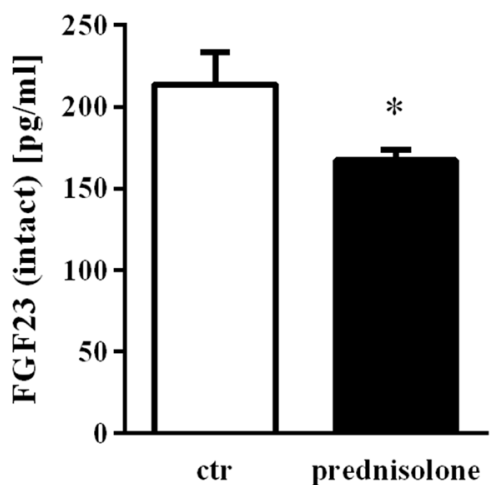


Fig. 3 The glucocorticoid effect on serum FGF23 and bone Fgf23 expression. Arithmetic means \pm SEM of the serum concentration of $\mathrm{C}$ terminal FGF23 (a, $n=11)$ and intact FGF23 $(\mathbf{b}, n=13)$ as well as relative osseous mRNA expression (c) of $F g f 23$ ( $n=7$, arbitrary units (a. u.), Dmpl $(\mathrm{n}=9)$, Phex $(\mathrm{n}=9)$, and Nfkbia $(\mathrm{n}=9)$ normalized to housekeeping gene Gapdh in control mice (ctr, white bars) and dexamethasonetreated mice (20 mg/kg body weight, DEXA, black bars) $12 \mathrm{~h}$ after injection. Arithmetic means \pm SEM of the serum concentration of $\mathrm{C}$ terminal $(\mathbf{d}, n=10)$ and intact FGF23 $(\mathbf{e}, n=10)$ in mice $12 \mathrm{~h}$ after treatment with vehicle (ctr, white bars) or prednisolone $(20 \mathrm{mg} / \mathrm{kg}$ body weight; black bars). $* p<0.05, * * p<0.01$ indicate significant difference compared to vehicle-treated mice. (a, c (right lower panel) and e: unpaired $t$ test with Welch's correction; b and c (right upper panel): unpaired $t$ test; c (left upper panel and left lower panel) and d: Mann-Whitney U test)

\section{Discussion}

Our study discloses glucocorticoids as powerful suppressors of the production of FGF23. We demonstrated in vitro and in vivo that the widely used glucocorticoids dexamethasone and prednisolone downregulate $F g f 23$ gene expression and lower the serum concentration of FGF23.

Dexamethasone is a synthetic glucocorticoid with high potency that is widely used in the treatment of inflammatory conditions, but also in cerebral edema and to prevent chemotherapy-induced nausea and vomiting [38]. In contrast to some other glucocorticoids, it has no considerable mineralocorticoid activity [45]. Prednisolone is widely used in autoimmune diseases including rheumatoid arthritis, polymyalgia rheumatica, or inflammatory bowel disease. Mineralocorticoid receptor agonists including aldosterone induce the synthesis of FGF23, as seen in primary and secondary hyperaldosteronism [46]. In contrast, our study reveals the GR as a negative regulator of FGF23.

The regulation of renal $\mathrm{Na}^{+}$-dependent phosphate transport by dexamethasone has been described before [40]. In their study, an inhibitory effect on the membrane expression of $\mathrm{NaP}_{i}$ paralleled by phosphaturia was found after 4 days of dexamethasone treatment [40]. We also observed phosphaturia in response to acute dexamethasone treatment. It is therefore possible that, apart from direct suppression of FGF23 as suggested by our cell culture experiments, dexamethasoneinduced phosphaturia also contributes to the suppression of FGF23 production.

We observed a strong and significant reduction of the FGF23 serum concentration as early as $12 \mathrm{~h}$ after a single dose of dexamethasone or prednisolone. Notably, both, C-terminal and intact FGF23 were reduced, suggesting that glucocorticoids indeed suppress $F g f 23$ gene expression rather than merely affecting post-translational processing. The latter would have been expected if C-terminal FGF23 had only been
Fig. 4 Impact of dexamethasone on $1,25(\mathrm{OH})_{2} \mathrm{D}_{3}$ formation, metabolism and PTH serum level. Arithmetic means \pm SEM $(n=6)$ of the $1,25(\mathrm{OH})_{2} \mathrm{D}_{3}(\mathbf{a})$ and intact PTH (b) serum concentration in control mice (ctr, white bars) and mice treated with $20 \mathrm{mg} / \mathrm{kg}$ body weight dexamethasone (DEXA, black bars) $12 \mathrm{~h}$ after the injection. Arithmetic means \pm SEM $(n=6$, arbitrary units (a. u.)) of relative mRNA transcript levels of Cyp27b1 (c) and Cyp24al (d) normalized to Gapdh in kidneys from mice $12 \mathrm{~h}$ after the injection of vehicle only (ctr, white bars) or $20 \mathrm{mg} / \mathrm{kg}$ body weight dexamethasone (DEXA, black bars). $* * p<0.01, * * * p<0.001$ indicate statistically significant differences from control-treated mice. (a, b and $\mathbf{d}$ : unpaired $t$ test; $\mathbf{c}$ : unpaired $t$ test with Welch's correction) a

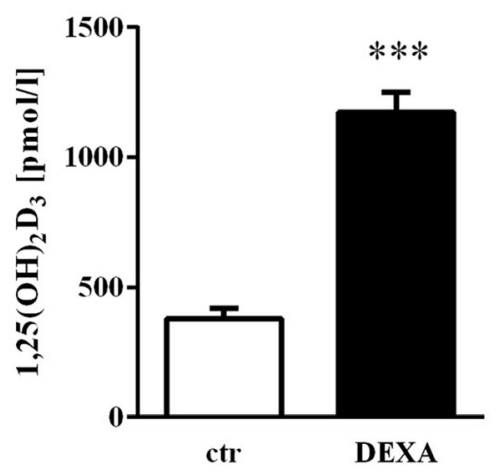

C

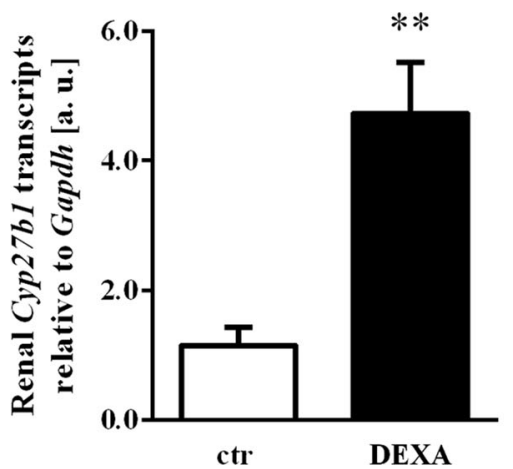

b

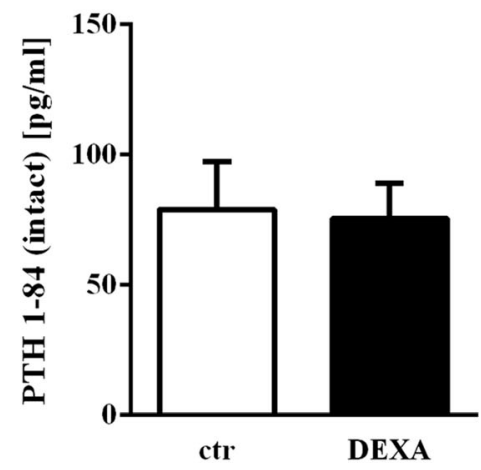

d

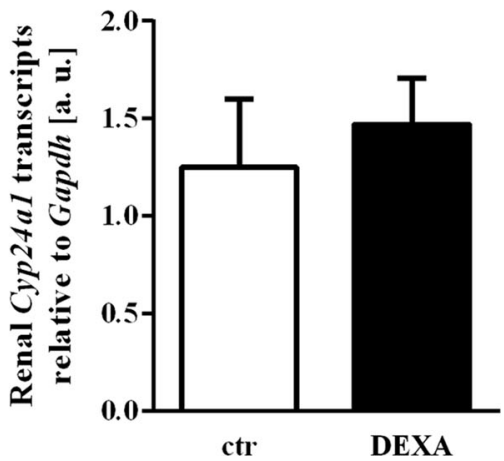


a

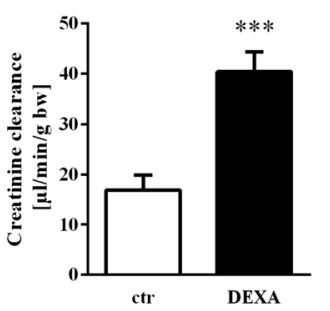

d

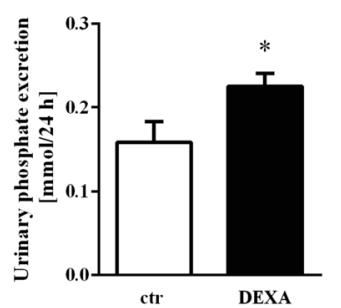

b

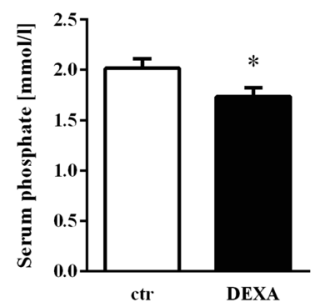

e

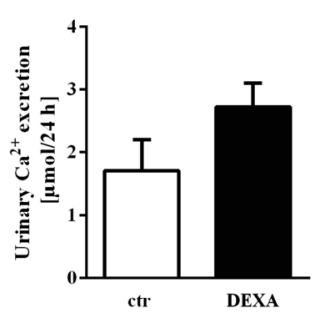

Fig. 5 Effect of dexamethasone on phosphate and $\mathrm{Ca}^{2+}$ metabolism. Arithmetic means \pm SEM of creatinine clearance $(\mathbf{a}, n=6)$, the serum concentration of phosphate (b, $n=17 ; 12 \mathrm{~h}$ after injection) and $\mathrm{Ca}^{2+}(\mathbf{c}$, $n=12 ; 12 \mathrm{~h}$ after injection), as well as phosphate $(\mathbf{d}, n=6)$ and $\mathrm{Ca}^{2+}(\mathbf{e}$, $n=6$ ) excretion in mice in $24 \mathrm{~h}$ urine after injection of vehicle (ctr, white bars) or $20 \mathrm{mg} / \mathrm{kg}$ body weight dexamethasone (DEXA, black bars). Arithmetic means $\pm \operatorname{SEM}(n=6$, arbitrary units (a. u.)) of relative

affected by the glucocorticoid. Short-term treatments even with very high doses of glucocorticoids are frequent in daily clinical practice. Therefore, our results may be of high relevance and glucocorticoid-dependent suppression of FGF23 a frequent phenomenon.

Due to the inhibitory effect of FGF23 on the formation of $1,25(\mathrm{OH})_{2} \mathrm{D}_{3}$, dexamethasone-dependent suppression of FGF23 could be expected to elevate the $1,25(\mathrm{OH})_{2} \mathrm{D}_{3}$ serum concentration. In line with this, we saw a surge in the $1,25(\mathrm{OH})_{2} \mathrm{D}_{3}$ serum level $12 \mathrm{~h}$ after the single dose of dexamethasone. In contrast, it is well-established textbook knowledge that particularly a long-term glucocorticoid therapy clinically indicated in various chronic autoimmune diseases requires the patient to take additional vitamin D to prevent bone loss [47], and steroid therapy is indeed associated with low $25(\mathrm{OH}) \mathrm{D}_{3}$ levels [48]. A glucocorticoid-induced increase in active vitamin D may therefore come as a surprise. It is, however, the logical consequence of the suppression of FGF23 formation by glucocorticoids. In addition, it must be kept in mind that our study only reflects the acute effects of a single dose of glucocorticoids within $12 \mathrm{~h}$. It is well conceivable that the immediate increase in the serum $1,25(\mathrm{OH})_{2} \mathrm{D}_{3}$ concentration due to a glucocorticoid-dependent downregulation of FGF23 is overridden by further direct and indirect effects of glucocorticoids on the bone and vitamin D metabolism in the long run resulting in the well-documented bone loss and vitamin $\mathrm{D}$ deficiency.

According to our results, neither $\mathrm{Ca}^{2+}$ metabolism nor PTH secretion was acutely affected by glucocorticoid administration.

C

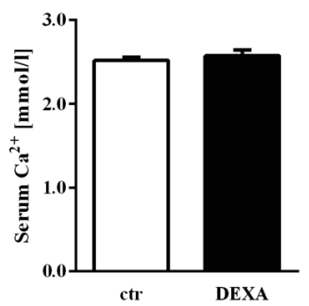

f

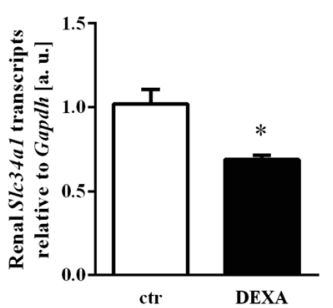

g

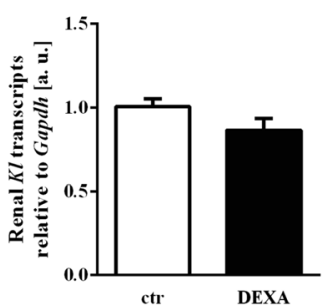

mRNA transcript levels of Slc34al (f) and $K l$ (g) normalized to Gapdh in kidneys from mice $12 \mathrm{~h}$ after the injection of vehicle (ctr, white bars) or $20 \mathrm{mg} / \mathrm{kg}$ body weight dexamethasone (DEXA, black bars). $* p<0.05$, $* * * p<0.001$ indicate statistically significant differences from control mice. (a, b, d, e and g: unpaired $t$ test; c: Mann-Whitney U test; f: unpaired $t$ test with Welch's correction)

In contrast, a long lasting steroid therapy favors renal $\mathrm{Ca}^{2+}$ loss and secondary hyperparathyroidism [49]. It appears to be likely that the acute effect of a glucocorticoid is therefore the downregulation of FGF23, whereas other effects on bone and $\mathrm{Ca}^{2+}$ and phosphate metabolism come later. Similar to the cell culture experiments, Nfkbia was upregulated in vivo, whereas Dmpl and $P$ hex were not significantly affected by dexamethasone treatment. In our in vivo study, glucocorticoid effects on blood parameters were determined after $12 \mathrm{~h}$ whereas urine was collected for $24 \mathrm{~h}$ in order to cover an entire day-night period. Hence, this may be a limitation of our study since glucocorticoids may affect circadian rhythm as well as urinary $\mathrm{Ca}^{2+}$ and phosphate excretion may be influenced by circadian rhythm. For technical reasons, pellets with different consistency had to be used in the metabolic cages. This diet had a slightly different composition compared to standard chow. However, since all ingredients were present in adequate amounts in both diets, this difference is unlikely to significantly affect the results.

A short-term glucocorticoid treatment is particularly relevant when strong anti-inflammatory (e.g., anaphylactic shock) or anti-emetic effects (e.g., chemotherapy) are needed. According to the results of this study, such a therapy could be paralleled by a decrease of FGF23 and a surge in $1,25(\mathrm{OH})_{2} \mathrm{D}_{3}$. The exact relevance of these anticipated changes in blood parameters needs to be defined in future clinical studies. However, it is intriguing to speculate that a decrease in the FGF23 serum level may indeed be beneficial as FGF23 has been shown to go up in various cardiovascular and renal 
diseases and in particular in those associated with inflammation.

Our cell culture studies disclosed that dexamethasone and prednisolone suppress $F g f 23$ gene expression in two bone cell lines. Moreover, this effect was paralleled by a lower C-terminal FGF23 protein concentration in the cell culture supernatant, i.e., secretion of FGF23 was also reduced by dexamethasone. Also the concentration of intact FGF23 tended to be lower in the supernatant from dexamethasone-treated cells although the values were below the detection limit for $50 \%$ of the samples. In both cell lines, Fgf 23 gene expression was induced by $1,25(\mathrm{OH})_{2} \mathrm{D}_{3}$ as described by others before [43]. The glucocorticoid effect on FGF23 could have been, at least in part, due to the crosstalk of $1,25(\mathrm{OH})_{2} \mathrm{D}_{3}$ and glucocorticoid signaling. However, the dexamethasone effect on upstream regulators of $F g f 23$ gene expression Dmpl, Phex, or Nfkbia was not altered by $1,25(\mathrm{OH})_{2} \mathrm{D}_{3}$. Therefore, it appears to be likely that glucocorticoids are not merely effective through suppression of $1,25(\mathrm{OH})_{2} \mathrm{D}_{3}$ signaling. However, these findings do not completely rule out that dexamethasone also downregulates $1,25(\mathrm{OH})_{2} \mathrm{D}_{3}$ signaling, at least to some extent. It must be kept in mind that the in vivo experiments clearly indicate that glucocorticoids indeed suppress FGF23, a finding suggesting that also the cell culture experiments reveal a relevant effect of glucocorticoids on FGF23.

Many of the multiple cellular effects of glucocorticoids can directly or indirectly be referred to their anti-inflammatory properties that are also the reason for their therapeutic potential in various diseases. Notably, inflammation in the form of transcription factor complex NFKB is a major driver of FGF23 production [28]. In an attempt to further characterize the molecular mechanism of the dexamethasone effect on FGF23 we found that dexamethasone induces gene expression of $\operatorname{I\kappa B} \alpha$, an inhibitor of $\mathrm{NF} \kappa \mathrm{B}$ that mediates anti-inflammatory effects of glucocorticoids [36]. Moreover, our experiments revealed that gene expression of FGF23 inhibitors dentin matrix acidic phosphoprotein 1 (Dmp1) and phosphate regulating endopeptidase homolog X-linked (Phex) [50] are also upregulated by dexamethasone [51] as has been shown by others before $[52,53]$. Hence, the glucocorticoiddependent inhibition of FGF23 is likely to be, at least in part, mediated by the glucocorticoid effects on I $\mathrm{K} B \alpha$, Dmp1, and Phex. Using glucocorticoid receptor antagonist RU-486, we could further demonstrate that the dexamethasone effects were, at least in part, mediated by the glucocorticoid receptor.

Taken together, our study demonstrates that glucocorticoids acutely downregulate the production of FGF23.

Supplementary Information The online version contains supplementary material available at https://doi.org/10.1007/s00109-021-02036-8 .

Acknowledgments The authors thank H. Froß, A. Ullrich, E. Kullick, C. Heidel, K. Bach, S. Ross, and F. Reipsch for technical help.

Authors' contribution MFe, GIS, and MFö designed research; MFe, JS, HS, DK-T, and MFö analyzed data; MFe, FE, JS, and PG performed research; and MFö and MFe wrote the paper. All authors revised and approved the final version of the manuscript.

Funding Open Access funding enabled and organized by Projekt DEAL. This work was supported by the Deutsche Forschungsgemeinschaft (FO $695 / 2-2)$.

Data availability The datasets generated during and/or analyzed during the current study are available from the corresponding author on reasonable request.

\section{Compliance with ethical standards}

Conflict of interests All authors state they have no conflicts of interest.

Ethics approval The animal experiments were approved by the state governments of Saxony-Anhalt (Landesverwaltungsamt Halle/Saale) and Baden-Württemberg (Regierungspräsidium Stuttgart).

\section{Consent for publication Not applicable.}

Open Access This article is licensed under a Creative Commons Attribution 4.0 International License, which permits use, sharing, adaptation, distribution and reproduction in any medium or format, as long as you give appropriate credit to the original author(s) and the source, provide a link to the Creative Commons licence, and indicate if changes were made. The images or other third party material in this article are included in the article's Creative Commons licence, unless indicated otherwise in a credit line to the material. If material is not included in the article's Creative Commons licence and your intended use is not permitted by statutory regulation or exceeds the permitted use, you will need to obtain permission directly from the copyright holder. To view a copy of this licence, visit http://creativecommons.org/licenses/by/4.0/.

\section{References}

1. Hu MC, Shi M, Moe OW (2019) Role of $\alpha$ Klotho and FGF23 in regulation of type II Na-dependent phosphate co-transporters. Pflugers Arch 471(1):99-108

2. Vervloet M (2019) Renal and extrarenal effects of fibroblast growth factor 23. Nature reviews. Nephrology 15(2):109-120

3. Li Y, Chen F, Wei A, Bi F, Zhu X, Yin S, Lin W, Cao W (2019) Klotho recovery by genistein via promoter histone acetylation and DNA demethylation mitigates renal fibrosis in mice. J Mol Med (Berl) 97(4):541-552

4. Mace ML, Gravesen E, Nordholm A, Olgaard K, Lewin E (2018) Fibroblast growth factor (FGF) 23 regulates the plasma levels of parathyroid hormone in vivo through the FGF receptor in normocalcemia, but not in Hypocalcemia. Calcif Tissue Int 102(1):85-92

5. Lanske B, Razzaque MS (2014) Molecular interactions of FGF23 and PTH in phosphate regulation. Kidney Int 86(6):1072-1074

6. Faul C, Amaral AP, Oskouei B, Hu M-C, Sloan A, Isakova T, Gutiérrez OM, Aguillon-Prada R, Lincoln J, Hare JM et al (2011) FGF23 induces left ventricular hypertrophy. J Clin Invest 121(11): 4393-4408

7. Rossaint J, Oehmichen J, van Aken H, Reuter S, Pavenstädt HJ, Meersch M, Unruh M, Zarbock A (2016) FGF23 signaling impairs neutrophil recruitment and host defense during CKD. J Clin Invest 126(3):962-974 
8. Singh S, Grabner A, Yanucil C, Schramm K, Czaya B, Krick S, Czaja MJ, Bartz R, Abraham R, Di Marco GS et al (2016) Fibroblast growth factor 23 directly targets hepatocytes to promote inflammation in chronic kidney disease. Kidney Int 90(5):985-996

9. Andrukhova O, Slavic S, Smorodchenko A, Zeitz U, Shalhoub V, Lanske B, Pohl EE, Erben RG (2014) FGF23 regulates renal sodium handling and blood pressure. EMBO Mol Med 6(6):744-759

10. Han X, Ross J, Kolumam G, Pi M, Sonoda J, King G, Quarles LD (2018) Cardiovascular effects of renal distal tubule deletion of the FGF receptor 1 gene. J Am Soc Nephrol 29(1):69-80

11. Faul C (2018) FGF23 effects on the heart-levels, time, source, and context matter. Kidney Int 94(1):7-11

12. Richter B, Faul C (2018) FGF23 actions on target tissues-with and without Klotho. Front Endocrinol 9:189

13. Kuro-o M, Matsumura Y, Aizawa H, Kawaguchi H, Suga T, Utsugi T, Ohyama Y, Kurabayashi M, Kaname T, Kume E et al (1997) Mutation of the mouse klotho gene leads to a syndrome resembling ageing. Nature 390(6655):45-51

14. Shimada T, Kakitani M, Yamazaki Y, Hasegawa H, Takeuchi Y, Fujita T, Fukumoto S, Tomizuka K, Yamashita T (2004) Targeted ablation of Fgf23 demonstrates an essential physiological role of FGF23 in phosphate and vitamin D metabolism. J Clin Invest 113(4):561-568

15. Carpinelli MR, Wise AK, Burt RA (2011) Vitamin D-deficient diet rescues hearing loss in Klotho mice. Hear Res 275(1-2):105-109

16. Kendrick J, Kestenbaum B, Chonchol M (2011) Phosphate and cardiovascular disease. Adv Chronic Kidney Dis 18(2):113-119

17. Isakova T, Cai X, Lee J, Xie D, Wang X, Mehta R, Allen NB, Scialla JJ, Pencina MJ, Anderson AH et al (2018) Longitudinal FGF23 trajectories and mortality in patients with CKD. J Am Soc Nephrol 29(2):579-590

18. Isakova T, Wahl P, Vargas GS, Gutiérrez OM, Scialla J, Xie H, Appleby D, Nessel L, Bellovich K, Chen J et al (2011) Fibroblast growth factor 23 is elevated before parathyroid hormone and phosphate in chronic kidney disease. Kidney Int 79(12):1370-1378

19. Schnedl C, Fahrleitner-Pammer A, Pietschmann P, Amrein K (2015) FGF23 in acute and chronic illness. Dis Markers 2015:1-8

20. Prié D, Friedlander G (2010) Reciprocal control of 1,25dihydroxyvitamin D and FGF23 formation involving the FGF23/ Klotho system. Clin J Am Soc Nephrol 5(9):1717-1722

21. Meir T, Durlacher K, Pan Z, Amir G, Richards WG, Silver J, Naveh-Many T (2014) Parathyroid hormone activates the orphan nuclear receptor Nurr1 to induce FGF23 transcription. Kidney Int 86(6):1106-1115

22. Vervloet MG, van Ittersum FJ, Büttler RM, Heijboer AC, Blankenstein MA, ter Wee PM (2011) Effects of dietary phosphate and calcium intake on fibroblast growth factor-23. Clin J Am Soc Nephrol 6(2):383-389

23. Francis C, David V (2016) Inflammation regulates fibroblast growth factor 23 production. Curr Opin Nephrol Hypertens 25(4): 325-332

24. Glosse P, Fajol A, Hirche F, Feger M, Voelk1 J, Lang F, Stangl GI, Föller M (2018) A high-fat diet stimulates fibroblast growth factor 23 formation in mice through TNF $\alpha$ upregulation. Nutri Diabetes $8(1): 36$

25. Durlacher-Betzer K, Hassan A, Levi R, Axelrod J, Silver J, NavehMany T (2018) Interleukin-6 contributes to the increase in fibroblast growth factor 23 expression in acute and chronic kidney disease. Kidney Int 94(2):315-325

26. David V, Martin A, Isakova T, Spaulding C, Qi L, Ramirez V, Zumbrennen-Bullough KB, Sun CC, Lin HY, Babitt JL et al (2016) Inflammation and functional iron deficiency regulate fibroblast growth factor 23 production. Kidney Int 89(1):135-146

27. Daryadel A, Bettoni C, Haider T, Imenez Silva PH, Schnitzbauer U, Pastor-Arroyo EM, Wenger RH, Gassmann M, Wagner CA (2018)
Erythropoietin stimulates fibroblast growth factor 23 (FGF23) in mice and men. Pflugers Arch 470(10):1569-1582

28. Zhang B, Yan J, Umbach AT, Fakhri H, Fajol A, Schmidt S, Salker MS, Chen H, Alexander D, Spichtig D et al (2016) NFkB-sensitive Orail expression in the regulation of FGF23 release. J Mol Med (Berl) 94(5):557-566

29. Ma K, Liu P, Al-Maghout T, Sukkar B, Cao H, Voelkl J, Alesutan I, Pieske B, Lang F (2019) Phosphate-induced ORAI1 expression and store-operated $\mathrm{Ca} 2+$ entry in aortic smooth muscle cells. J Mol Med (Berl) 97(10):1465-1475

30. Bär L, Feger M, Fajol A, Klotz L-O, Zeng S, Lang F, Hocher B, Föller M (2018) Insulin suppresses the production of fibroblast growth factor 23 (FGF23). Proc Natl Acad Sci U S A 115(22): 5804-5809

31. Feger M, Hase P, Zhang B, Hirche F, Glosse P, Lang F, Föller M (2017) The production of fibroblast growth factor 23 is controlled by TGF- $\beta 2$. Sci Rep 7(1):4982

32. Thau L, Gandhi J, Sharma S (2020) Physiology, Cortisol. In: StatPearls. Treasure Island (FL): StatPearls . Available from: https://www.ncbi.nlm.nih.gov/books/NBK538239/. Accessed Jan 2020

33. Timmermans S, Souffriau J, Libert C (2019) A general introduction to glucocorticoid biology. Front Immunol 10:1545

34. Goulding NJ, Guyre PM (1993) Glucocorticoids, lipocortins and the immune response. Curr Opin Immunol 5(1):108-113

35. Herold MJ, McPherson KG, Reichardt HM (2006) Glucocorticoids in T cell apoptosis and function. Cell Mol Life Sci 63(1):60-72

36. Auphan N, DiDonato JA, Rosette C, Helmberg A, Karin M (1995) Immunosuppression by glucocorticoids: inhibition of NF-kappa B activity through induction of I kappa B synthesis. Science 270(5234):286-290

37. Kleiman A, Tuckermann JP (2007) Glucocorticoid receptor action in beneficial and side effects of steroid therapy: lessons from conditional knockout mice. Mol Cell Endocrinol 275(1-2):98-108

38. Liu D, Ahmet A, Ward L, Krishnamoorthy P, Mandelcorn ED, Leigh R, Brown JP, Cohen A, Kim H (2013) A practical guide to the monitoring and management of the complications of systemic corticosteroid therapy. Allergy, Asthma Clin Immunol 9(1):30

39. Weinstein RS (2011) Clinical practice. Glucocorticoid-induced bone disease. N Engl J Med 365(1):62-70

40. Levi M, Shayman JA, Abe A, Gross SK, McCluer RH, Biber J, Murer H, Lötscher M, Cronin RE (1995) Dexamethasone modulates rat renal brush border membrane phosphate transporter mRNA and protein abundance and glycosphingolipid composition. J Clin Invest 96(1):207-216

41. Zhang J, Song J, Shao J (2015) Icariin attenuates glucocorticoidinduced bone deteriorations, hypocalcemia and hypercalciuria in mice. Int J Clin Exp Med 8(5):7306-7314

42. Delucchi Á, Toro L, Alzamora R, Barrientos V, González M, Andaur R, León P, Villanueva F, Galindo M, Las Heras F et al (2019) Glucocorticoids decrease longitudinal bone growth in pediatric kidney transplant recipients by stimulating the FGF23/FGFR3 signaling pathway. J Bone Miner Res 34:1851-1861

43. Saini RK, Kaneko I, Jurutka PW, Forster R, Hsieh A, Hsieh J-C, Haussler MR, Whitfield GK (2013) 1,25-dihydroxyvitamin D(3) regulation of fibroblast growth factor- 23 expression in bone cells: evidence for primary and secondary mechanisms modulated by leptin and interleukin-6. Calcif Tissue Int 92(4):339-353

44. Baylis C, Brenner BM (1978) Mechanism of the glucocorticoidinduced increase in glomerular filtration rate. Am J Phys 234(2): F166-F170

45. Lan NC, Graham B, Bartter FC, Baxter JD (1982) Binding of steroids to mineralocorticoid receptors: implications for in vivo occupancy by glucocorticoids. J Clin Endocrinol Metab 54(2):332-342

46. Zhang B, Umbach AT, Chen H, Yan J, Fakhri H, Fajol A, Salker MS, Spichtig D, Daryadel A, Wagner CA et al (2016) Up- 
regulation of FGF23 release by aldosterone. Biochem Biophys Res Commun 470(2):384-390

47. Moghadam-Kia S, Werth VP (2010) Prevention and treatment of systemic glucocorticoid side effects. Int J Dermatol 49(3):239-248

48. Skversky AL, Kumar J, Abramowitz MK, Kaskel FJ, Melamed ML (2011) Association of glucocorticoid use and low 25hydroxyvitamin D levels: results from the National Health and nutrition examination survey (NHANES): 2001-2006. J Clin Endocrinol Metab 96(12):3838-3845

49. Suzuki Y, Ichikawa Y, Saito E, Homma M (1983) Importance of increased urinary calcium excretion in the development of secondary hyperparathyroidism of patients under glucocorticoid therapy. Metabolism 32(2):151-156

50. Liu S, Zhou J, Tang W, Menard R, Feng JQ, Quarles LD (2008) Pathogenic role of Fgf23 in Dmp1-null mice. American journal of physiology. Endocrinol Metab 295(2):E254-E261
51. Yao W, Cheng Z, Pham A, Busse C, Zimmermann EA, Ritchie RO, Lane NE (2008) Glucocorticoid-induced bone loss in mice can be reversed by the actions of parathyroid hormone and risedronate on different pathways for bone formation and mineralization. Arthritis Rheum 58(11):3485-3497

52. Mikami Y, Takahashi T, Kato S, Takagi M (2008) Dexamethasone promotes DMP1 mRNA expression by inhibiting negative regulation of Runx2 in multipotential mesenchymal progenitor, ROBC26. Cell Biol Int 32(2):239-246

53. Hines ER, Collins JF, Jones MD, Serey SH, Ghishan FK (2002) Glucocorticoid regulation of the murine PHEX gene. Am J Physiol Renal Physiol 283(2):F356-F363

Publisher's note Springer Nature remains neutral with regard to jurisdictional claims in published maps and institutional affiliations. 